\title{
DETERMINANTS OF PROFESSIONAL MOTIVATION OF SOCIAL WORKERS WORKING WITH PEOPLE WITH DISABILITIES
}

\author{
Remigijus Bubnys \\ Siauliai University, Lithuania \\ Eglè Milašiūtè \\ Siauliai University, Lithuania
}

\begin{abstract}
The main precondition for good care of people with disabilities is not only social workers' knowledge of pedagogical, psychological or social work but also their own personal qualities, values, attitudes, empathy and psychological resilience in difficult situations. Professional motivation encompasses employees' motives and needs guiding them to purposefully certain personal and organisational goals. Motivation is the basis and the cause of the professional activity, which is related to the satisfaction of the employee's needs and which may be conditioned by the employee's experience. Problems of the research: What are the intrinsic and extrinsic factors of social worker's motivation to work? The aim is to analyse the motivation factors of professional activities of social workers working with people with disabilities. Research methods: 1) A semi-structured interview for data collection; 2) A qualitative content analysis based on the content of the analysed text. Sample. The survey involved 12 social workers from Lithuania who work with with people having disabilities. The results disclose intrinsic and extrinsic factors of social workers' professional motivation in Lithuania. Extrinsic factors that stimulate social workers are not the main source of motivation for work. Social workers point out that the main factors driving employees to work are the pay, working conditions and work environment, well-being in the work environment, positive feedback from the manager, co-workers' support and trust, client appreciation, manager praise. Intrinsic factors promoting social workers' professional activities are selfrealization, opportunities for improvement, clients' well-being, training in supervision, qualification improvement.
\end{abstract}

Keywords: motivation, professional motivation, people with disabilities, social work, social workers.

\section{Introduction}

The social worker's activity influenced by changes in knowledge, skills and values tends to turn into the professional and creative activity responding to actualities of social change (Kavaliauskienè \& Nikolajenko, 2017). To ensure effective professional activities of social work specialists, it is necessary to pay much attention to employee motivation and motivating (Lipinskiené, 2012). 
Bubnys \& Milašiūtè, 2020. Determinants of Professional Motivation of Social Workers Working with People with Disabilities

Having chosen the social worker's profession and performing such duties, the person's motivation acquires particular importance: this helps to achieve a high professional level, treating one's work as meaningful and seeking good performance (Lepeškienė \& Žuromskaja, 2012). Motivation for the professional activity is a system of behavioural incentives, which is generated by various motives behind one's work. Motivated employees create attractive work environment, work more professionally and effectively (Šinkūnienè \& Katkoniene, 2010). Scientists working in the social work field pay attention to the social worker's motivation function aiming to: improve the social worker's functioning, develop professional culture, consolidate professional identity, develop the ability to cognize, understand the ever-changing social reality, create the opportunity for every social worker to become a valued professional while providing quality social services to clients of different levels (Kavaliauskienè \& Nikolojenko, 2017). The choice and use of different forms of motivation motivate the employee in his/her professional activity, promote him/her to provide quality services and improve, reflect on value orientations; therefore, motivation trends are the key to successful social work, especially working with people having disabilities (Richard et al., 2001; Zaviršek, 2009). According to Juodaityte and Jablonskienè (2013), motivation at work can be described as the totality of the very employee and psychosocial factors of his/her surrounding environment, which stimulates work activities and determines the form, direction, intensity and duration of professional activities. Motivation at work encourages to focus and act purposively, seeking the match between personal needs and organisational interests, provides value and meaning to the activity (Morkevičiūtè, Endriulaitienè, \& Jočienè, 2018).

Social workers' motivation to perform professional activities becomes relevant because in many countries, the field of social work and social services is attributed to the fields of higher occupational risk (Žibènienè \& Mikniūtè, 2016). Working with the people having disabilities, social workers often encounter psychological problems (Lloyd, 2002; Huxley, 2005; Diržytė et al., 2010; Wilberforce et al., 2014) which often leads to the reduction of employees' motivation to work and refusal to stay in this field of professional activity any longer (Kim \& Stoner, 2008; Webb \& Carpenter, 2012). Thus, social work with people having disabilities is a specific area requiring great effort and abilities from social workers. This field poses numerous problems determining that the social worker is less interested and motivated to work, which often leads to withdrawal from this professional field, choosing another less "sensitive" group of clients. The main aim of enhancing motivation is to improve the social worker's functioning, professional culture, strengthen professional identity by developing the ability to cognize and understand the constantly changing social reality, enable every social worker to become a recognized professional 
(Kavaliauskienė \& Nikolajenko, 2017). Modern and often chaotic society changes the attitude towards the employee and his/her motivating, because the organization's success depends on its employees; therefore, it is relevant to find out what factors motivate employees to perform their work in a quality manner today (Adomaityte, Girdvainytè, \& Martinkiene, 2016). The problem question formulated in this study is: What intrinsic and extrinsic factors of professional motivation determine successful performance of the social worker's activity, working with people having disabilities?

The object of the research: motivational factors for social workers' professional activities. The aim of the research: to analyse the experience of social workers working with people with disabilities, distinguishing motivational factors for professional activities.

\section{Material and Methods}

Seeking to analyse motivational factors of social workers working with people having disabilities to perform professional activities, data was collected choosing a semi-structured interview method. The interview questionnaire consisted of open-ended questions to find out the extrinsic and intrinsic motivational determinants of social workers working with people with disabilities. The data analysis was performed employing the content analysis method (Žydžiūnaitė \& Sabaliauskas, 2018).

The study involved 12 social workers. The data was collected until it started showing repeats and a decrease in informative capacity became obvious, in other words, until data saturation substantiating a statement proving that the revealed features exist was achieved (Saunders et al., 2018) As professional motivation is important to all social workers providing services to persons with different types of disabilities, a convenience, purposive non-probability sampling was chosen to conduct the study (Žydžiūnaitė \& Sabaliauskas, 2018). Applying this selection method, the most easily accessible research participants working with persons who have different disabilities were selected.

\section{Research Results}

Work with people with disabilities may require particular psychological resources; therefore, first of all, it is necessary to take care of the employee's psychological state and quality of life. Positive well-being at work is an important factor determining job satisfaction and effectiveness, working with people having disabilities (Kreivinienè \& Vaičiulienè, 2015). In the initial stage of the study, it was sought to find out social workers' emotional state in the work environment, which, as shown in the studies conducted by many scientists, 
Bubnys \& Milašiūtè, 2020. Determinants of Professional Motivation of Social Workers Working with People with Disabilities

influences the social worker's motivation to perform activities. This article presents and analyses data; i.e., presents major categories the notional content of which coincided for more than half of research participants. The analysis of data resulted in distinguishing two categories and eight subcategories justifying them (see Table 1):

Table 1 Social workers' emotional state in the work environment

\begin{tabular}{|l|l|}
\hline CATEGORY & SUBCATEGORY \\
\hline \multirow{4}{*}{ Positive microclimate in the organization } & Positive feelings \\
\cline { 2 - 2 } & Enjoyable job \\
\cline { 2 - 2 } & Sense of security \\
\cline { 2 - 2 } & Supportive environment \\
\hline \multirow{4}{*}{ Negative microclimate in the organization } & Experienced tension \\
\cline { 2 - 2 } & Manifestations of stress \\
\cline { 2 - 2 } & Negative atmosphere in the workplace \\
\cline { 2 - 2 } & Experienced difficulties \\
\hline
\end{tabular}

The category "Positive microclimate in the organization" reflects that social workers experience positive feelings in their work environment and this determines their job satisfaction:

“... At work, I feel well enough...”; “... I feel very well in my work environment and I am satisfied with my job ...”; "... my emotional state at work is almost always good ...”; “... I feel wonderful, pleased with my job ...”.

The obtained results confirm the results of conducted studies that wellbeing in the work environment ensures the employee's sense of security, positive disposition, not only increases effectiveness at work but also promotes the employee's motivation and job satisfaction (Lipinskienè, 2012). The statements of study participants also testify to the fact that social workers do the enjoyable job, feel support and security:

“... for me, work is like a holiday, I feel great ...”; “... I'd say well because I'm doing the work I like ...”; “... I really like such work ...”; “... if everything is calm, well, you feel safe enough ...”.

According to Viningiene (2012), well-being in the work environment influences employees' job satisfaction and quite considerably affects work motivation.

Four subcategories came to prominence in the category "Negative microclimate in the organization". The subcategory "Experienced tension", which collected most notional units, revealed negative feelings experienced by employees in the work environment. The statements of research participants can be related to Klokmaniene's (2014) opinion that due to the occupational risk in social work with people with disabilities, employees may encounter the lack of security, fear, feel constant anxiety and risk. It should be envisaged that most 
often, social workers carry out their activities in the positive microclimate (positive feelings at work), experience positive emotions (feel good because they do the enjoyable job, are supported and feel secure), and these factors motivate them for professional activities. The study revealed that there were also such employees who felt bad in their work environment because of the negative microclimate in their workplace: they experienced tension, felt stress and negative atmosphere, which suggests that these factors may determine social workers' demotivation for professional activities.

The person's integration into the labour market is subject to many individual, social and economic factors. Career design is one of the determinants of professional success. The choice of the profession is perceived as the aspect of giving a sense to the professional activity, as the combination of the potential of the professional activity, personal qualities and self-motivation. As every employee is individual, the motives promoting to work are different. Encouraging the employee to be motivated while performing his/her duties, it is sought to apply the individualised system of promotion in social work practice. It was aimed to find out the strongest motivators of social workers in their professional activities. After performing content analysis of research participants' data, five key categories and their constitutive sub-categories were distinguished, revealing the most motivating factors in the social worker's professional activity (see Table 2).

Table 2 Factors promoting social workers' professional motivation

\begin{tabular}{|l|l|}
\hline CATEGORY & SUBCATEGORY \\
\hline \multirow{4}{*}{ Meeting personal needs } & Physiological needs \\
\cline { 2 - 2 } & Security needs \\
\cline { 2 - 2 } & Social needs \\
\cline { 2 - 2 } & Self-esteem and recognition needs \\
\hline \multirow{4}{*}{$\begin{array}{l}\text { Organisational culture and } \\
\text { psychological working conditions }\end{array}$} & Common goals and traditions \\
\cline { 2 - 2 } & Supportive position of the manager \\
\cline { 2 - 2 } $\begin{array}{l}\text { Professional and personal } \\
\text { development opportunities }\end{array}$ & Positive relationships with co-workers \\
\cline { 2 - 2 } $\begin{array}{l}\text { Communication and provision of } \\
\text { assistance }\end{array}$ & Satisfaction with the physical work environment \\
\cline { 2 - 2 } & In-service training \\
\hline $\begin{array}{l}\text { Altruistic commitment and respect } \\
\text { for the people having disabilities }\end{array}$ & $\begin{array}{l}\text { Communication and maintaining the relationship with } \\
\text { the people with disabilities }\end{array}$ \\
\cline { 2 - 2 } & Opportunity to help people \\
\cline { 2 - 2 } & Assistance without expecting material reward \\
\hline
\end{tabular}


Bubnys \& Milašiūtè, 2020. Determinants of Professional Motivation of Social Workers Working with People with Disabilities

Motivation for the professional activity encourages to focus and act purposively, seeking compatibility of personal needs and organisational interests, gives greater value and meaning to the activity (Markevičiūte, Endriulaitienè, \& Jočienè, 2018). The first two categories, "Meeting personal needs" and "Organizational culture and psychological working conditions" namely reveal main personal and the organisation's intrinsic motivational factors. Meeting personal needs in professional activities is directly related to the pay that employees receive for their work:

“... I would be lying if I said that it doesn't matter ... so that I could meet my needs, be recognised because I am a professional in my field, but I am paid almost the minimum salary...”; "... in any case, the salary is important for various personal needs and, still there are taxes, rent, a car ...".

The content of constitutive sub-categories testifies to considerable importance of the pay for meeting social workers' security needs. According to Lipinskiene (2012), based on the theory of justice, the employee should receive such remuneration that would correspond to his/her input and ensure his/her feelings of security and self-esteem.

The analysis of the research participants' experiences also showed that they testified to good psychological working conditions in their work:

"Comfort in the team and the manager's authority are great stimuli to work, create a good atmosphere ..."; "In our work, much attention is paid to the psychological working conditions, great care is taken of employees' mental health, employees get the psychologist's consultations".

The psychological environment is the organisational culture comprised of management structure, work style, values, traditions and work ethic (Čapienè \& Merkiene, 2014). Social workers point out particular importance of the psychological means created by their organization's manager, shaping the organisation's general work culture. Social workers distinguish the manager's behaviour (the leadership style) and good work atmosphere as very important motivating factors in the work environment.

The category "Professional and personal development opportunities" and the content of its constitutive sub-categories reveal that involvement in the continuous learning process and development of competencies in the various inservice training courses are a particularly important social workers' motivational factor.

“... in-service training courses enabling me to provide increasingly better quality assistance to clients ..."; “... in this work we have huge funding for in-service training courses, I am curious and that is why this encourages me ...”.

Based on Žaptorius' (2007) research results, it can be stated that career and professional development opportunities, participation in courses, seminars, comprehensive improvement of employees as professionals, supervisions are 
important for social workers. Research participants indicated the importance of personal development and career aspiration. Statements of research participants reveal opportunities, interests and priorities, seeking personal development:

“... I think improvement of myself as an employee ...”; “... like I said, I really want to improve as much as possible so that I can be a professional in my field and maybe then the opportunity to climb the career ladder would appear...”.

The experiences imparted by social workers enable to assume that the freedom of choice and personal development are a significant motivational factor. Work in the organisation can be successful when the individual realizes his/her personal potential and pursues life goals by improving professionally and as a personality (Lipinskienè, 2012). Research participants' experiences coincide with Petružytè's (2013) research results demonstrating that in the definition of the social work law, legal acts and codes of ethics, self-realization as the vision of social work is identified as one of the essential goals in professional activities.

The content of the category "Communication and provision of assistance" reveals that one of the essential factors promoting professional motivation is communication with clients, making a contact with them and supporting them because of the opportunity to help them:

"... in general, I really enjoy working with people when you can constantly communicate...”; “... I like communicating with people having disabilities and this actually encourages me to undertake activities ...”.

The category "Altruistic commitment and respect for the people with disabilities" highlights the trend that most social workers do not give prominence to the material reward in their work with the disabled and work being promoted by personal professional calling and commitment rather than the pursuit for selfish goals. The results of the study confirmed Viningiene's (2012) research results revealing that employees who rationally assume responsibility at work are more motivated by intrinsic factors in their professional activities:

“... you think that maybe you don't need to try so hard because the salary is low, but the people with disabilities $d$ are not guilty for that and maybe I couldn't behave differently, I feel respect, no matter how much I get, let's say ...".

People are less motivated or demotivated by various factors that can be determined by both personal and environmental circumstances; therefore, hindrances arising at work affect employee motivation (William, 2010). The question "What factors motivate you less in social work?" was given to find out the factors demotivating social workers in their professional activities. After analysing the results of research participants, 3 categories and their 8 constitutive sub-categories, which reveal demotivating factors in the professional activity with people having disabilities, were distinguished (see Table 3). 
Bubnys \& Milašiūtè, 2020. Determinants of Professional Motivation of Social Workers Working with People with Disabilities

Table 3 Demotivating factors in social work

\begin{tabular}{|l|l|}
\hline CATEGORY & SUBCATEGORY \\
\hline \multirow{3}{*}{ Psychosocial work environment } & Lack of security \\
\cline { 2 - 2 } & Negative atmosphere and climate \\
\cline { 2 - 2 } & Physical work environment \\
\hline \multirow{3}{*}{$\begin{array}{l}\text { Interrelation with the manager, co-workers } \\
\text { and clients }\end{array}$} & Absence of feedback \\
\cline { 2 - 2 } & Absence of support from the manager \\
\cline { 2 - 2 } & Lack of mutual understanding and cooperation \\
\cline { 2 - 2 } & Clients' negative assessment \\
\hline Social economic factors & Low salary \\
\hline
\end{tabular}

The content of sub-categories distinguished in the category "Psychosocial work environment" suggests that the lack of security at work is one of the demotivating factors. Social workers note that there are quite many situations at work when they feel insecure. They also note that work motivation is influenced by the dominant atmosphere. The atmosphere arousing dissatisfaction and negative emotions at work particularly reduces the desire to work:

"... sometimes the dismal work environment is unsatisfying ...”; “... in my work environment I don't feel well at times, sometimes I feel negative atmosphere ...”; "... it's not always good at work, that negative climate in the work environment does not make me happy ...”.

In many cases, demotivation of social workers arises within the organization itself due to the formed emotional atmosphere between employees, employees and clients, managers. According to Klokmanienè (2014), the work atmosphere, psychological environment are a particularly significant factor motivating employees. The negative atmosphere in the work environment causes the employee's job dissatisfaction.

The sub-category "Low salary", grounded in the category "Social economic factors", reflects research participants' dissatisfaction with the pay they receive:

“... salary, well, sometimes it doesn't promote ...”; “... there are times when I

think that we work almost for the minimum salary, this sometimes really doesn't encourage ..."; “... sometimes I lose motivation when I get a pay slip ...”

It is noteworthy that the data seem to be ambiguous: in one case social workers work on an altruistic basis; and in another case, because of the salary. This can be explained by the fact that the poor material reward is more related to the content of personal life in order to meet personal needs. This factor was not distinguished as relevant and significant in the context of the experiences in relation to the people with disabilities. Social workers' dissatisfaction with low salaries, which is identified as demotivating, confirms Viningienè's (2014) opinion that one of the most important factors determining work motivation is the salary and its amount, which would let the employee feel that he/she has received a fair reward for performed work. If the salary is too low, the employee 
may feel dissatisfaction that in some cases manifests itself as reluctance to try one's best at work.

The content of the subcategories distinguished in the category "Interrelationship with the manager" reveals that social workers do not receive feedback and support from their manager in their professional activities. According to Lipinskiene (2012), employees' motivation is significantly influenced by the management style, attention to employees, support, communication: when the manager fails to lead appropriately, employees' motivation decreases. The analysis of the research data enables to envisage that positive interpersonal relationships with colleagues are very important for social workers providing services to the people with disabilities: friendly, collegial relationships grounded on support, trust and assistance are of particular importance to motivation for performing professional activities. Mutual agreement in the team is necessary not only seeking effective teamwork but also improving the general work atmosphere motivating employees to work.

The content of experiences of social workers' relationships with the client reveals that employees feel clients' dissatisfaction with the provided recommendations for ensuring personal well-being. It should be assumed that clients often express dissatisfaction with the recommendations they receive. The importance of assessing client-employee relationships is confirmed by a study conducted by Ožeraitienè, Gaigalaitè, Arnatkevič (2014), stating that positive evaluation of employees by clients motivate employees to pursue personal and organisational goals. Employee recognition and praise can do as much as the material incentive to keep people motivated and assured of their value.

\section{Conclusions}

Intrinsic factors determining social workers' motivation for professional activities include seeking the client's and personal well-being, communication and maintaining the relation with clients, professional development, courses and in-service training, self-realization through assistance provision, personal and professional abilities, and self-realisation through job satisfaction.

The extrinsic factors influencing social workers' motivation for professional activities include positive means of the manager's influence on subordinates: mutual understanding, cooperation, promoting leadership style, positive interpersonal relationships with colleagues, positive evaluation of social workers by clients, non-material incentives. Factors ensuring successful performance of activities and job satisfaction also include psychological working conditions - positive psychological climate and culture in the organisation - as well as physical working conditions. 
Bubnys \& Milašiūtè, 2020. Determinants of Professional Motivation of Social Workers Working with People with Disabilities

Extrinsic factors that demotivate social workers in their professional activities most are the lack of security at work, work atmosphere causing negative emotions, dissatisfaction with the pay, problems of interpersonal communication between colleagues, with clients and the organization's manager.

\section{References}

Adomaitytè, G., Girdvainytė, V., \& Martinkienè, J. (2016). Motyvacijos metodai šiuolaikinèse imonèse. Akademinio jaunimo siekiai: ekonomikos, vadybos ir technologiju ịžvalgos, 32-40.

Čapienè, A., \& Merkienè, R. (2014). Studentų motyvavimo veiksniai ir priemonès, užtikrinančios aktyvų dalyvavimą verslumo ugdymo praktikoje. Management Theory and Studies for Rural Business and Infrastructure Development, 36(2), 224-254.

Diržytė, A., Bandzevičienè, R., \& Dauderys, V. (2010). Dirbančiųų su neịgaliaisiais vidinès darnos, gyvenimo kokybės ir streso ịveikos ypatumai. Socialiniu mokslu studijos, 4(8), 7-20.

Galambos, C.M. (2004). Social Work Practice with People with Disabilities: Are We Doing Enough? Health \& Social Work, 29(3), 163-165.

Huxley, P., Evans, S., Gately, C., Webber, M., Mears, A., Pajak, S., Kendall, T., Medina, J.,\& Katona, C. (2005). Stress and Pressure in Mental Health Social Work: The Worker Speaks. British Journal of Social Work, 35(7), 1063-1079.

Juodaitytè, A., \& Jablonskienè, Z. (2013). Personalo motyvacijos ir lojalumo ir skatinimo organizacijai psichosocialiniai veiksniai. Profesinès studijos: teorija ir praktika, 12(12), 87-96.

Kavaliauskienè, V., \& Nikolajenko, E. (2017). Nuostatos kaip socialinio darbuotojo profesinès veiklos motyvaciją skatinantis veiksnys. Tiltai, 2, 41-52.

Kim, H., \& Stoner, M. (2008). Burnout and Turnover Intention Among Social Workers: Effects of Role Stress, Job Autonomy, and Social Support. Administration in Social Work, 32(3), 5-25.

Klokmanienè, D., \& Klokmanienè, L. (2014). Suauge socialinès rizikos žmonès. Socialinis darbas. Panevėžys: Panevěžio kolegija.

Kreivinienė, B., \& Vaičiulienė, J. (2012). Asmenų, turinčių negalią, gyvenimo kokybė: subjektyvus požiūris. Tiltai, 2, 133-142.

Lepeškienè, V., \& Žuromskaja, J. (2012). Socialinio darbo studentų savo asmenybès savybių vertinimas ir jų sąsajos su pasirinkimo studijuoti socialini darbą motyvais ir ketinimu ji dirbti. Socialine teorija, empirija, politika ir praktika, 6, 33-44.

Lipinskienè, D. (2012). Motyvuojanti atlygio sistema. Kaunas: Technologija.

Lloyd, C., King, R., \& Chenoweth, L. (2002). Social Work, Stress and Burnout: A Review. Journal of Mental Health, 11(3), 255-265.

Morkevičiūtè, M., Endriulaitienè, A., \& Jočienè, E. (2018). Darbo motyvacija: priklausomybės nuo darbo prevencijos priemonè ar rizikos veiksnys? Visuomenés sveikata, 2(81), 32-39.

Ožeraitienė, V., Gaigalaitienė, V., \& Arnatkevič, J. (2014). Profesinès veiklos vidinès motyvacijos ir pasitenkinimo darbu charakteristiku tyrimas. Medicinos teorija ir praktika, 20(4), 292-298. 
Petružytė, D. (2013). Kliento savirealizacija kaip socialinio darbo tikslas: pagalbos teikimo organizavimo galimybès, Tiltai, 14(65), 139-159.

Richard, L., Beaulaurier, D., Samuel H., \& Taylor, DSW. (2001). Social Work Practice with People with Disabilities in the Era of Disability Rights. Social Work in Health Care, 32(4), 67-92.

Saunders, B., Sim, J., Kingstone, T. et al. (2018). Saturation in Qualitative Research: Exploring its Conceptualization and Operationalization. Quality \& Quantity, 52, 18931907.

Šinkūnienè, J.R., \& Katkonienè, A. (2010). Socialinių darbuotojų profesinès veiklos motyvacijos veiksniai. Socialinis darbas, 9(1), 64-73.

Viningienè, D. (2012). Darbuotoju darbo motyvacijos ir pasitenkinimo darbu sąsajos. Regional Formation and development studies, 1(6), 161-170.

Webb, C.M., \& Carpenter, J. (2012), What Can be Done to Promote the Retention of Social Workers? A Systematic Review of Interventions. British Journal of Social Work, 42(7), 1235-1255.

Wilberforce, M., Jacobs, S., Challis, D., Manthorpe et al. (2014). Revisiting the Causes of Stress in Social Work: Sources of Job Demands, Control and Support in Personalised Adult Social Care. British Journal of Social Work, 44(4), 812-830.

William, A.N. (2010). Employee motivation and performance. Mikkeli: Mikkeli University of Applied Sciences.

Zaviršek, D. (2009). Social Work with Adults with Disabilities: An International Perspective. The British Journal of Social Work, 39(7), 1393-1405.

Žaptorius, J. (2007). Darbuotojų motyvacijos sistemos kūrimas ir jos teorinè analizè. Filosofija. Sociologija, 105-117.

Žibėnienė, G., \& Mikniūtè, A. (2016). Socialinių darbuotojų, dirbančių su socialinès rizikos šeimomis, požiūris ị profesinę riziką. Socialinis darbas, 14(2), 148-161.

Žydžiūnaitė, V., \& Sabaliauskas, S. (2017). Kokybiniai tyrimai, principai ir metodai. Vilnius: leidykla VAGA. 